\title{
Simultaneous inversion of the aftershock data of the 1993 Killari earthquake in Peninsular India and its seismotectonic implications
}

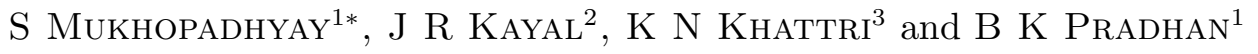 \\ ${ }^{1}$ Department of Earth Sciences, Indian Institute of Technology (formerly University of Roorkee), \\ Roorkee, Uttaranchal 247 667, India \\ ${ }^{2}$ Geological Survey of India, Central Geophysics Division, 27 J.L.N. Road, Kolkata 700 016, India \\ ${ }^{3} 100$ Rajendra Nagar, Dehra Dun, Uttaranchal 248 001, India \\ *e-mail:sagarfes@iitr.ernet.in
}

The aftershock sequence of the September 30th, 1993 Killari earthquake in the Latur district of Maharashtra state, India, recorded by 41 temporary seismograph stations are used for estimating 3 -D velocity structure in the epicentral area. The local earthquake tomography (LET) method of Thurber (1983) is used. About $1500 P$ and $1200 S$ wave travel-times are inverted. The $P$ and $S$ wave velocities as well as $V_{P} / V_{S}$ ratio vary more rapidly in the vertical as well as in the horizontal directions in the source region compared to the adjacent areas. The main shock hypocentre is located at the junction of a high velocity and a low velocity zone, representing a fault zone at 6-7 km depth. The estimated average errors of $P$ velocity and $V_{P} / V_{S}$ ratio are $\pm 0.07 \mathrm{~km} / \mathrm{s}$ and \pm 0.016 , respectively. The best resolution of $P$ and $S$-wave velocities is obtained in the aftershock zone. The 3-D velocity structure and precise locations of the aftershocks suggest a 'stationary concept' of the Killari earthquake sequence.

\section{Introduction}

A devastating earthquake $\left(m_{b}=6.3\right)$ occurred in the early morning ( $03 \mathrm{~h} 55 \mathrm{~m}$ local time) of September 30th, 1993 in the southern part of the stable continental region (SCR) of Peninsular India, in the Latur district of Maharashtra state, India. The earthquake caused widespread damage; about 8,000 people died, 16,000 injured and more than 200,000 houses were extensively damaged in 2400 villages spread across 13 districts of the state of Maharashtra (GSI 1996; Seeber et al 1996). A maximum intensity of VIII+ (MSK scale) was assigned to this earthquake (figure 1).

The hypocentre parameters (table 1 ) of the main shock were reported by the United States Geological Survey (USGS), GEOSCOPE (Baumbach et al 1994), Harvard University (HRV), India Mete- orological Department (IMD) and National Geophysical Research Institute (NGRI). The NGRI location included the global network data, the national network (IMD) data and the data of the NGRI/GEOSCOPE observatory at Hyderabad, the nearest station to the epicenter. The NGRI location is shown in figure 1 . The epicenter lies near the Killari village, at the junction of the Tirna river and its tributary. The focal depth of the main shock is, however, debated. The various estimated depths that range from $2.6 \mathrm{~km}$ to $15 \mathrm{~km}$ are shown in table 1. Kayal (2000), based on aftershock investigation results, argued that the most acceptable focal depth of the main shock is $7 \pm 1 \mathrm{~km}$ as estimated by Chen and Kao (1995). The fault-plane solution of the main shock, as reported by the USGS, reveals a reverse faulting. The Centroid Moment Tensor (CMT) solution by the HRV also shows a reverse

Keywords. Killari earthquake aftershocks; simultaneous inversion; stable continental region. 


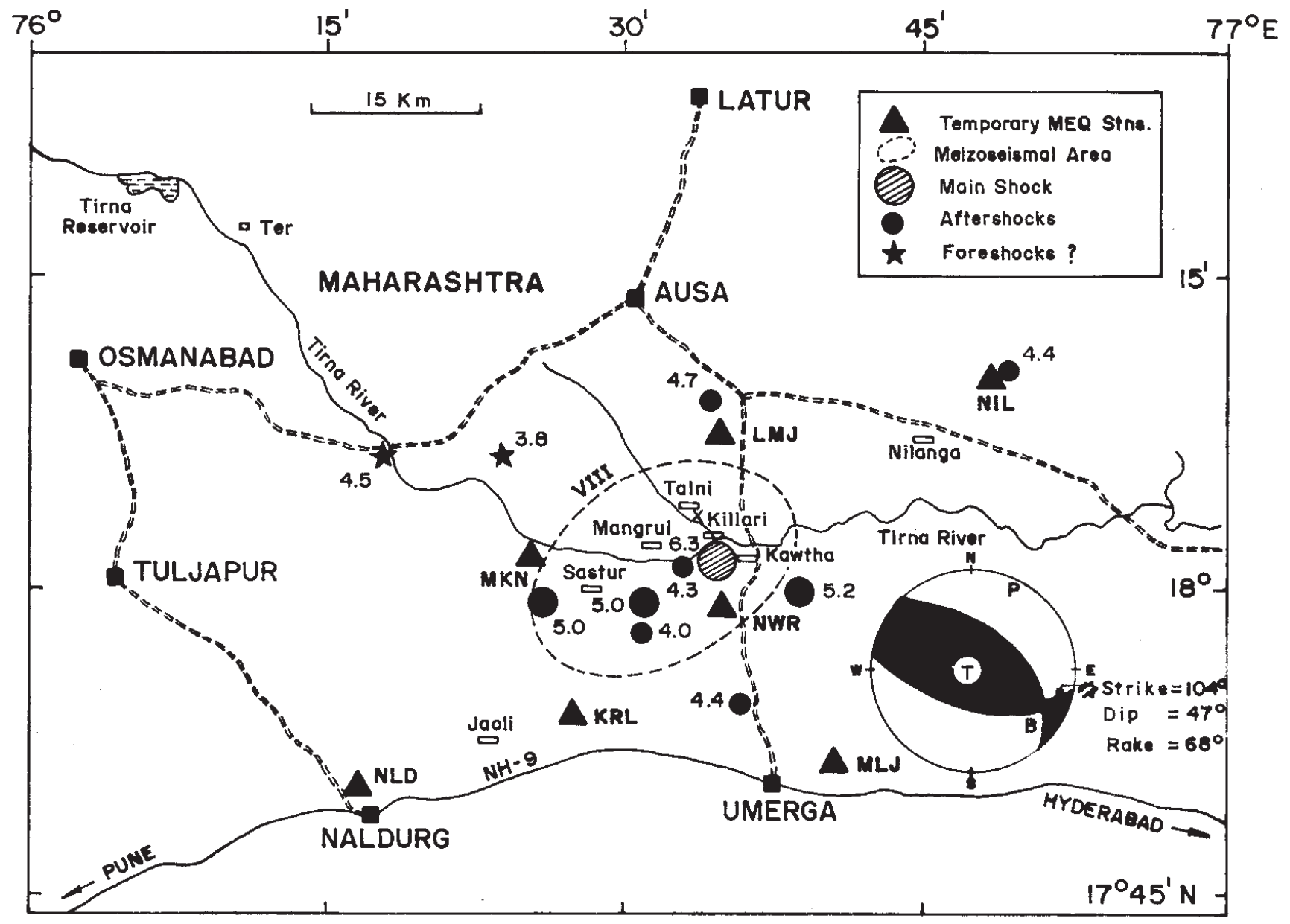

Figure 1. Map showing the main shock epicentre (NGRI), meizoseismal zone (intensity VIII) and the fault plane (CMT) solution of the main shock (after Kayal 2000).

faulting; both the solutions suggest dip slip motion with a small strike-slip component (figure 1).

Fortyone temporary microearthquake (MEQ) stations were established by various national and international organizations to monitor the aftershocks. They have analyzed their respective network data and reported about the seismicity pattern (Baumbach et al 1994; Kayal et al 1996; Gupta et al 1998). No report is, however, published on the 3-D velocity structure of the Killari earthquake source area. In the present work, we have used the collated seismic phase data recorded by the above 41-station MEQ network for the estimation of 3-D velocity structure by the local earthquake tomography (LET) method, and relocated the aftershocks. Results of this study are presented here.

Table 1. Main shock parameters.

\begin{tabular}{lccccl}
\hline $\begin{array}{l}\text { Origin time } \\
(\text { UTC })\end{array}$ & $\begin{array}{c}\text { Lat. } \\
{ }^{\circ} \mathrm{N}\end{array}$ & $\begin{array}{c}\text { Long. } \\
{ }^{\circ} \mathrm{E}\end{array}$ & $\begin{array}{c}\text { Depth } \\
\mathrm{km}\end{array}$ & $\begin{array}{c}\text { Magnitude } \\
m_{b}\end{array}$ & Source \\
\hline $22: 25: 48.6$ & 18.07 & 76.45 & 6.8 & 6.3 & USGS \\
$22: 25: 48.6$ & 18.02 & 76.56 & 15.0 & 6.1 & GEOSCOPE \\
$22: 25: 48.01$ & 18.01 & 76.56 & 6.0 & $6+$ & NGRI \\
$22: 25: 48.11$ & 18.11 & 76.55 & 15.0 & & HRV \\
$22: 02: 49.35$ & 18.07 & 76.62 & $6-12$ & 6.3 & IMD \\
& & & $7 \pm 1$ & & Chen and Kao (1995) \\
& & & $6.5 \pm 0.1^{*}$ & & Ramesh and Estabrook (1998) \\
& & & $2.6 \pm 1.0^{*}$ & & Seeber et al (1996) \\
\hline
\end{tabular}

${ }^{*}$ Centroid depth. The GEOSCOPE data are after Baumbach et al (1994). 


\section{Geology and tectonic setting}

Geologically the area belongs to the Deccan Trap Plateau basalts of the Paleocene age that are composed of a series of lava-flows in western and central India (Wadia 1998). The Deccan Traps lie unconformably on the Precambrian basement of the Indian shield. Since the Deccan Trap lava blanketed pre-existing tectonic features over a considerable area, the stratigraphy of the underlying formations is a matter of wide speculation. If continuation of the older formations exposed on the fringes of the Deccan Traps is assumed, then it may be inferred that the underlying formations may be any one or more of the Precambrian Dharwar formations, Precambrian granites and gneisses, Proterozoic Kaladgi and Bhima sediments and Gondwana (Permo-Carboniferous to Jurassic) sedimentary formations (Mohan and Rao 1994).

The ancient shields are, in general, stable except for the continental margins, rift zones etc. The southern part of the Peninsular India has long been described as a region of low seismicity. Recently the 1997 Jabalpur earthquake $\left(m_{b} 6.0\right)$ occurred in the Narmada-Son Lineament (NSL) rift zone, and occurred in the area where seismic activity is known to be present (Acharyya et al 1998; Rajendran and Rajendran 1998). On the other hand, the seismic hazard zonation map of India (Krishna 1992) depicts that the Killari area falls to the south of the NSL zone, which is marked as zone-I, and is generally regarded to be stable.

However, it is reported that before the Killari earthquake of September 30th, 1993, there were a number of smaller magnitude shocks between October and November, 1992 (Baumbach et al 1994; Gupta et al 1998). Twenty six tremors were recorded by the NGRI/GEOSCOPE observatory at Hyderabad Seismological Observatory from October 18th to November 15th, 1992 in the Killari region. The largest magnitude earthquake, $(M=4.0)$ was recorded on October 18th, 1992. As there were no seismic stations in the vicinity of this activity, shocks with magnitude less than 2.0 could not be recorded. Khattri (1994) attributes the seismicity of Peninsular India to block tectonics with a strain field being caused by the Indian plate motion. According to this hypothesis, the earthquakes are expected to occur at the boundary of the two blocks. The significant faults are either in NE or NW directions.

Detailed geophysical investigations comprising of gravity, magnetic, magnetotelluric and deep resistivity surveys were carried out in the Killari area after the main shock. The detailed gravity survey revealed three faults, two in the E-W and the other in the NW-SE directions in the epicentral area (Mishra et al 1994). Ramchandran and Kesava- mani (1997) made a detailed structural interpretation of the regional gravity map, and delineated a major structural discontinuity (called BLHV) in segments from west coast to east coast. They further suggested that several transverse faults transect the BLHV in NE-SW, N-S and NW-SE directions. In the Killari area it is in NW-SE direction. Sarma et al (1994) have reported the results of 16 wide band range $\left(10^{3} \mathrm{~Hz}-10^{-3} \mathrm{~Hz}\right)$ magnetotelluric soundings conducted in the region. They found an anomalously shallow upper crustal conductor in the hypocentral zone embedded in a high resistive upper crust at a depth of $6-8 \mathrm{~km}$. The conductor is oriented in a WNW-ESE direction. In a review paper, Kayal (2000) suggested that the Killari earthquake and its aftershocks involved interaction of two faults beneath the study area.

\section{Data sources}

The aftershocks were recorded by both analog and digital seismographs of the temporary and permanent networks. Fortyone temporary stations started operating eight to ten days after the main shock and continued for four months. The temporary stations were installed and operated by the Geological Survey of India (GSI), the India Meteorological Department (IMD), the Wadia Institute of Himalayan Geology (WIHG), Delhi University and by the German Task Force (GTF) team in collaboration with the National Geophysical Research Institute (NGRI). The GSI established a five-station MEQ network equipped with PS-2 (kinemetrics) analog recorders on October 8th, 1993. This network was run till 16th February, 1994 (Kayal et al 1996). The IMD also operated five microearthquake (MEQ) stations with analog recorders. The WIHG and the Delhi University operated two stations each with analog and digital recorders respectively. The NGRI installed seven single component analog recorders. All the analog seismographs were operated with vertical component seismometer. The GTF team established five 3-channel digital data acquisition systems, four three-component strong-motion recording instruments, and eleven analog systems; these stations were run till the end of December 1993 (Baumbach et al 1994).

The three permanent stations, viz., those at Hyderabad, Bombay and Poona, were the nearest (distance $<300 \mathrm{~km}$ ) observatories which recorded only a few aftershocks of relatively greater magnitude $\left(M_{D}>2.5\right)$. As these stations are too far away from the study area, the few aftershock phase-data were not enough to provide adequate ray coverage between the aftershock zone and these stations. 

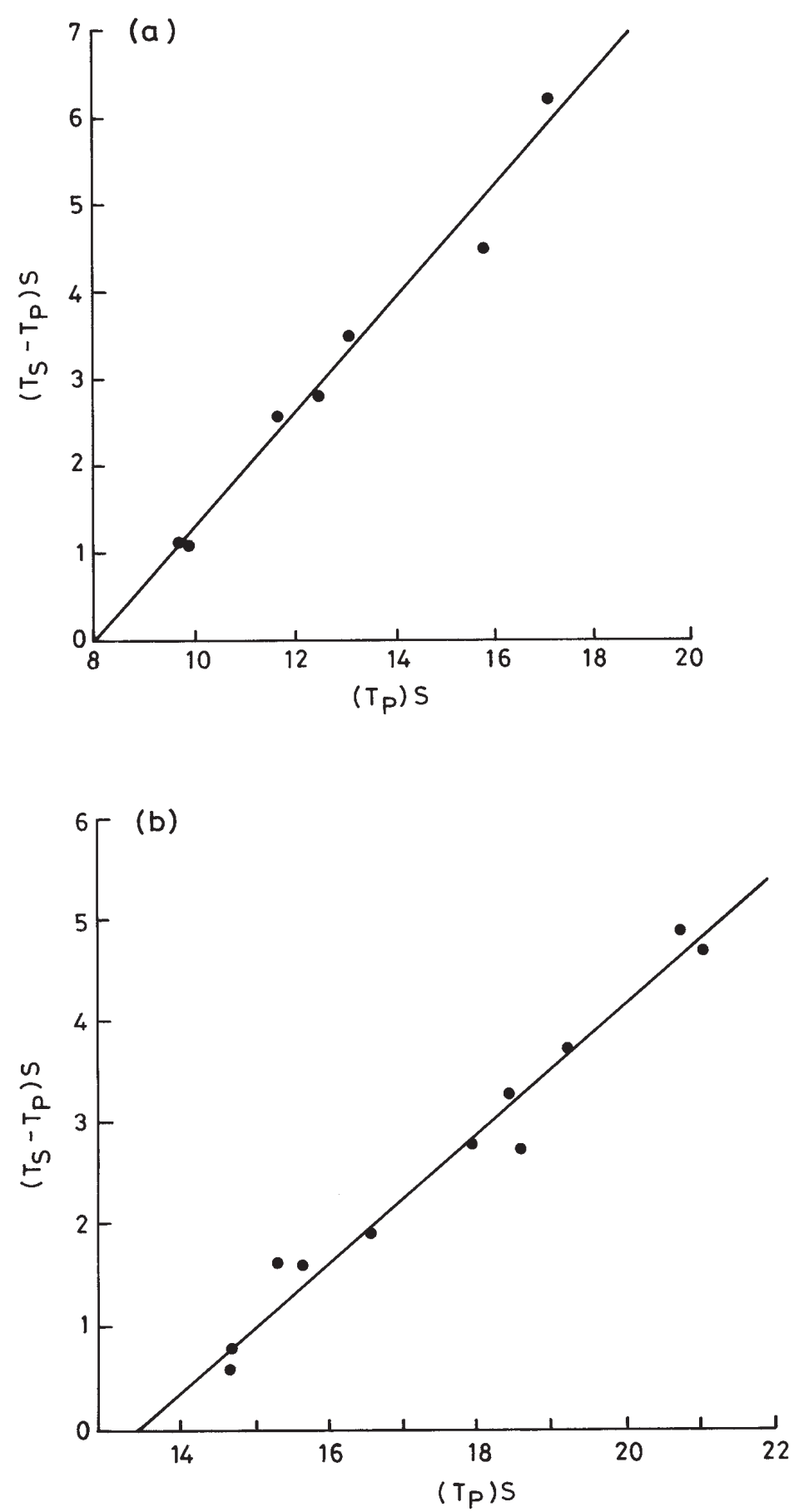

Figure 2. Examples of Wadati diagrams showing good fit of the data.

Hence, the permanent station data were ultimately not used in this study.

A total number of 210 aftershocks recorded by the temporary stations were selected for initial analysis. For all the aftershocks Wadati diagrams were drawn to check the quality of the data. Two representative Wadati diagrams are shown in figures 2(a) and (b). The $S$ phase data for stations for which the data points in the Wadati diagram showed large fluctuation from a straight line fit (more than 1 standard deviation) were removed.
After careful examination of the $P$ - and $S$-phase data, it was found that 22 events provide inadequate information required for simultaneous inversion; these events were discarded. Finally, 188 events with about $1500 P$-arrival and $1200 S$ arrival data were used for the inversion.

\section{Data analysis}

In order to use the LET program to find 3D velocity structure as well as improved estimates of 


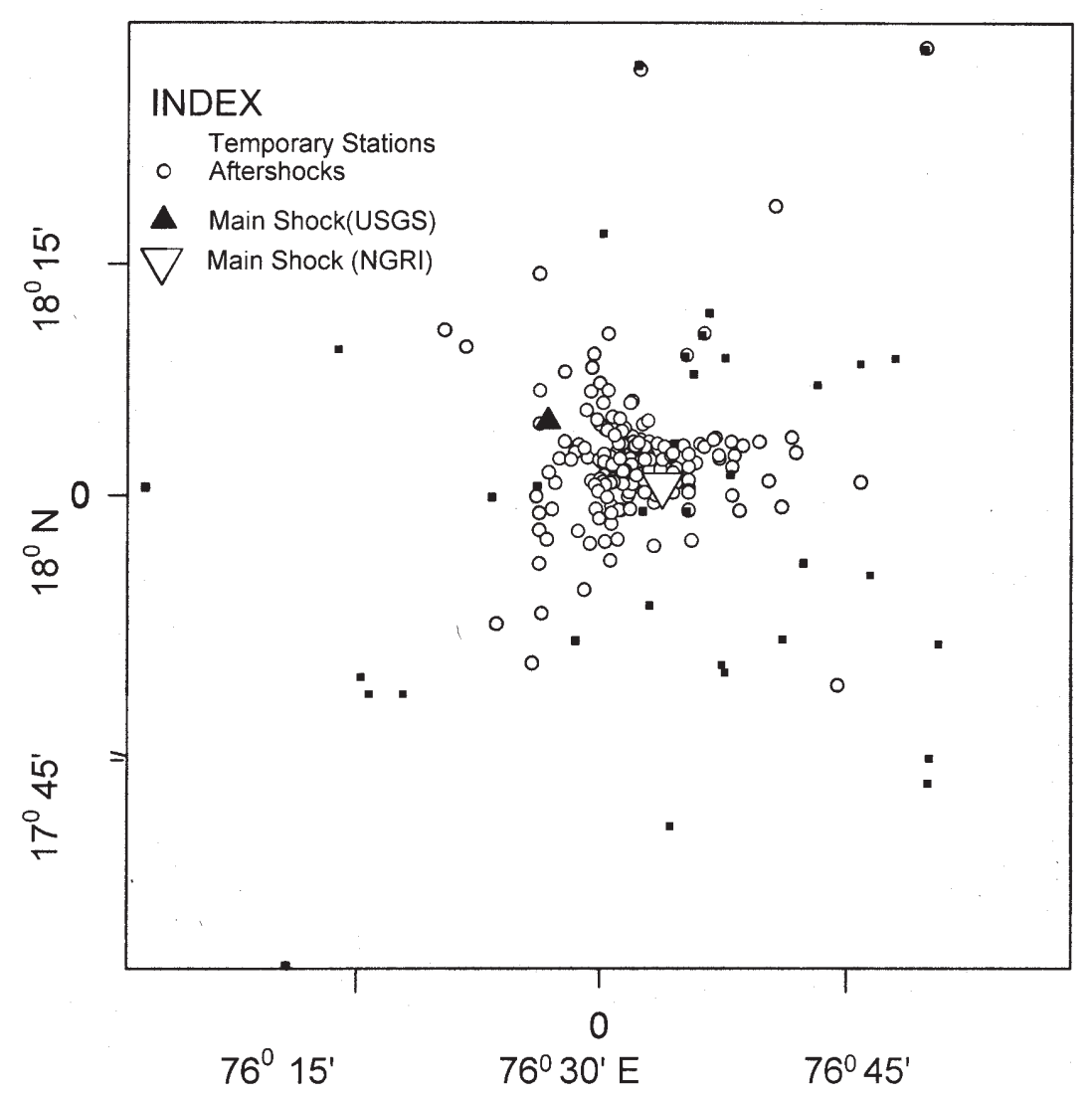

Figure 3. Map showing initial estimates of the aftershock epicenters using a 1-D velocity model and HYPO-71 program (see text). The NGRI and USGS estimates of the main shock are shown by inverted open and filled triangles, respectively.

hypocentral parameters, one needs to know at least a $1 \mathrm{D}$ velocity model of the area, and the preliminary estimates of hypocentral parameters. Pradhan (1999) used the Wadati-Riznichenko method (Simpson and Nicholson 1985) to determine the 1D velocity structure and used the HYPO71 program (Lee and Lahr 1975) for obtaining preliminary estimates of hypocentral parameters. He obtained a velocity of $4.95 \mathrm{~km} / \mathrm{s}$ for the upper most $2 \mathrm{~km}$, $5.82 \mathrm{~km} / \mathrm{s}$ for the next $10 \mathrm{~km}$ and $6.61 \mathrm{~km} / \mathrm{s}$ for the crust below $10 \mathrm{~km}$.

For the final analysis, the method of LET, as given by Thurber (1983) and later modified by Eberhart-Phillips (1993), was used. This method parallels that of Aki and Lee (1976). The fundamental improvement by Thurber (1983) used in this method is the use of $3 \mathrm{D}$ ray-tracing to calculate $P$-wave travel time (forward modelling). This permits the treatment of laterally varying velocity structure, which in turn allows for iterative improvement of the solution of earthquake locations and three dimensional earth structure. Eberhart-Phillips (1993) modified the program so that $S$-wave arrivals could also be incorporated for the estimation of 3-D variation of $S$ velocity and that of the $V_{P} / V_{S}$ ratio. The inverse problem to be formulated is generally overdetermined and the earth structure is represented in three dimensions by the velocity defined at a large number of discrete grid points, in contrast to the model of Aki and Lee (1976) where velocities are described inside the volume of each block. The velocity at a given point is determined by interpolation among the surrounding grid points. The incorporation of the $3 \mathrm{D}$ ray tracing permits the solution to be achieved iteratively. An important consequence is that the variance reduction achieved at each iteration can be directly computed rather than merely estimated as in the case of Aki and Lee (1976).

For choosing the area for 3D velocity study, the initial HYPO71 estimates of epicenters and the seismograph-station locations were plotted on a map (figure 3). Their areal distribution was considered to fix the spread of the model along EW and NS directions. Along both these directions the model area was restricted within $100 \mathrm{~km}$, keeping the center of the model at $18^{\circ} \mathrm{N}$ and $76^{\circ} 30^{\prime} \mathrm{E}$. Figures $4(\mathrm{a})$ and (b) show the E-W and N-S oriented depth sections, respectively, of the initial hypocentres located by using the $1 \mathrm{D}$ velocity model (table 2 ). It shows that for a number of earthquakes, fixed-depth solutions were obtained. The vertical extent of the 


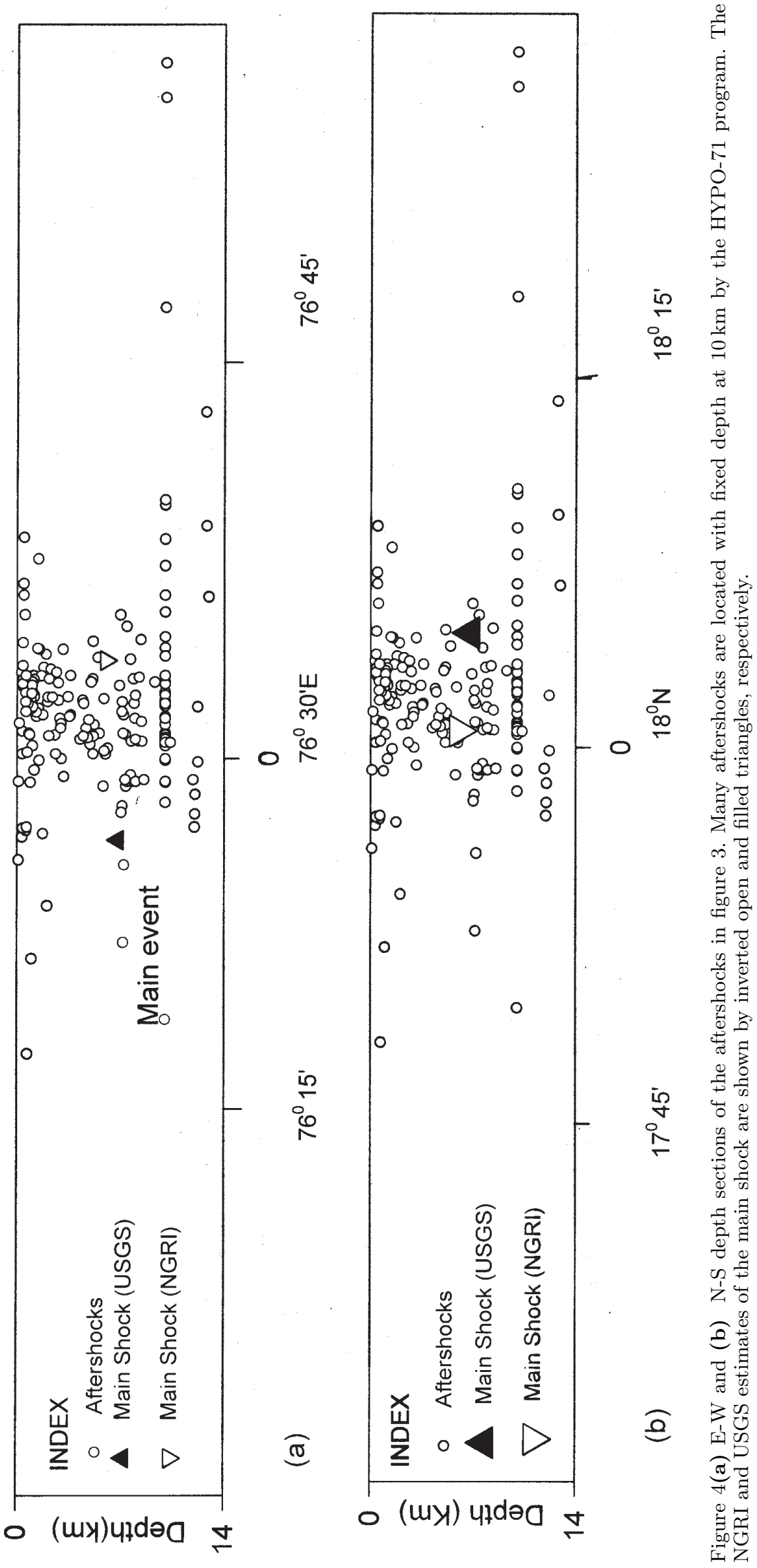


Table 2. Initial velocity model used for preliminary location using HYP071 (Lee and Lahr 1975) and as a starting model for LET (Thurber 1983).

\begin{tabular}{cc}
\hline $\begin{array}{c}\text { Depth to the top of the layer } \\
\text { in km }\end{array}$ & $\begin{array}{c}P \text { wave velocity } \\
\text { in } \mathrm{km} / \mathrm{s}\end{array}$ \\
\hline 0 & 4.95 \\
2 & 5.82 \\
12 & 6.61 \\
\hline
\end{tabular}

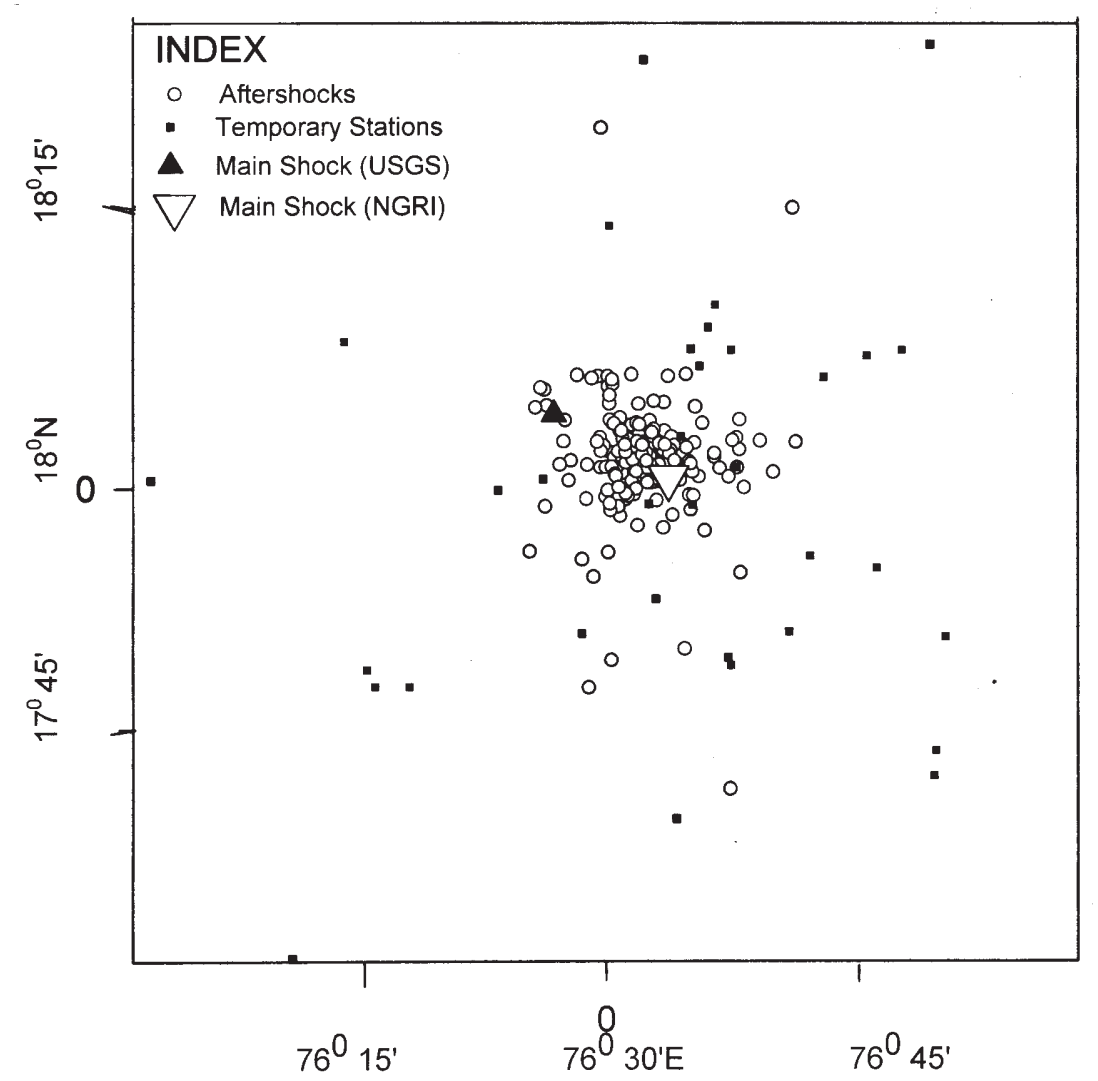

Figure 5. Map showing the relocated epicentres of the aftershocks using the 3-D simultaneous inversion technique. The NGRI and USGS estimates of the main shock are shown by inverted open and filled triangles, respectively.

model volume was constrained to be $14 \mathrm{~km}$ from the maximum depth of the events in figure 4 .

\section{Results}

The epicenters of the aftershocks located by the LET are shown in figure 5. It appears that most of the aftershocks occurred in a cluster. The NGRI estimated epicenter of the main shock falls on the SE corner of this cluster, whereas the USGS estimated epicenter of the main shock is located about 4 to $5 \mathrm{~km} \mathrm{NW}$ of this cluster. Figures 6 ( $\mathrm{a}$ and b) show the E-W and N-S depth sections of the aftershocks located by the LET on which the estimated 3 -D velocity models along $18^{\circ} \mathrm{N}$ and $76.5^{\circ} \mathrm{E}$ respectively are superimposed. It is plotted on a 1:1 scale.
If we join the trace of the coseismic surface rupture on this section with the main shock hypocentre as determined by the NGRI then we find that the aftershocks are mostly clustered around this line. We infer this line to be the projection of the thrust plane on which the main shock occurred for the following reasons.

- The dip of this thrust plane $\left(50^{\circ} \mathrm{S}\right)$ is compatible with that of the fault plane $\left(47^{\circ} \mathrm{S}\right)$ of the main shock inferred from the CMT solution by HRV.

- The coseismic rupture zone and the main shock lie on this plane.

- Most of the aftershocks cluster around this plane.

A horizontal slice at the depth level $6 \mathrm{~km}$ through the estimated velocity model shows that the focus of the main shock falls on the boundary between a low velocity and a high velocity zone (figure 7 ). It 

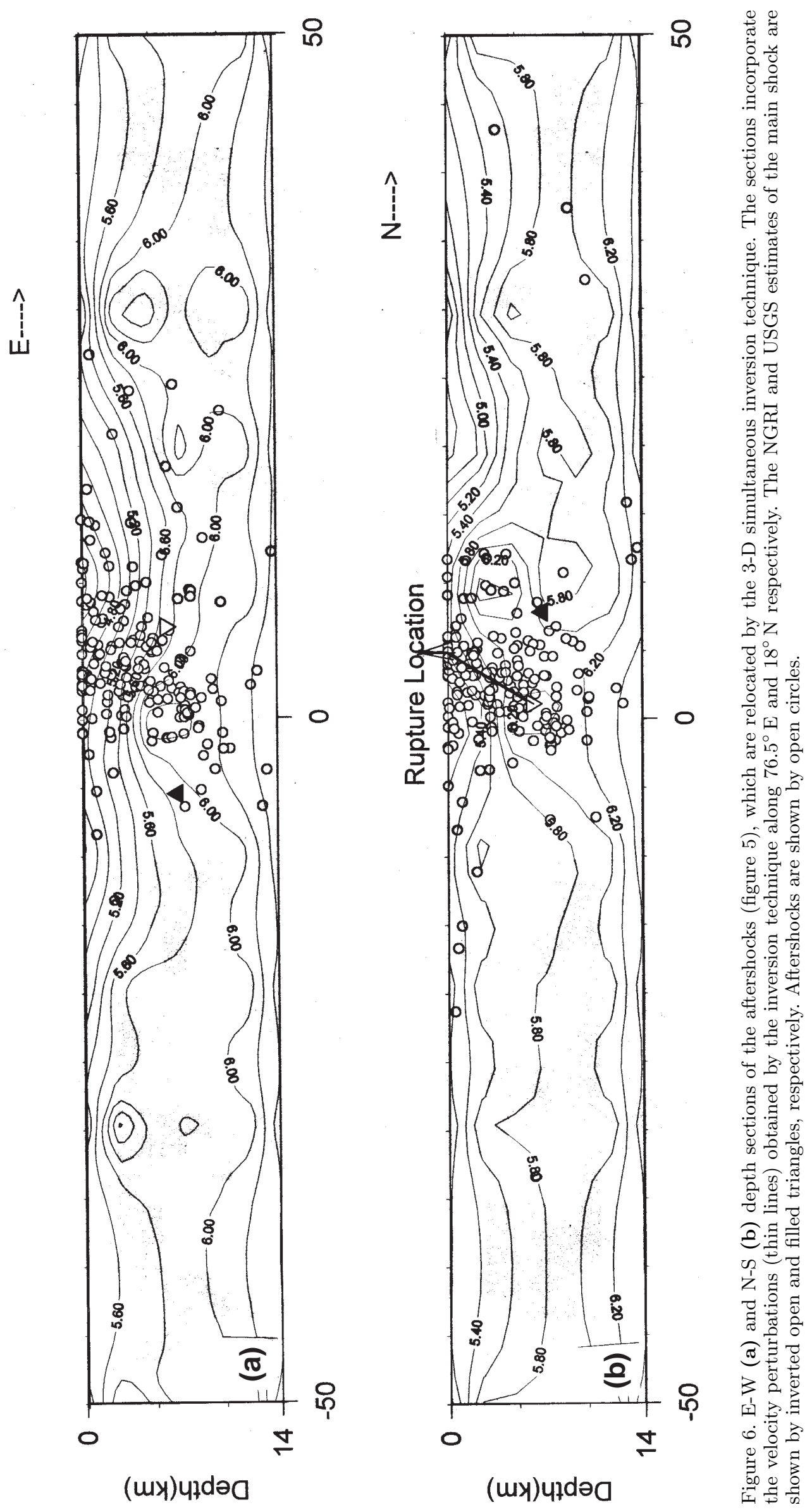


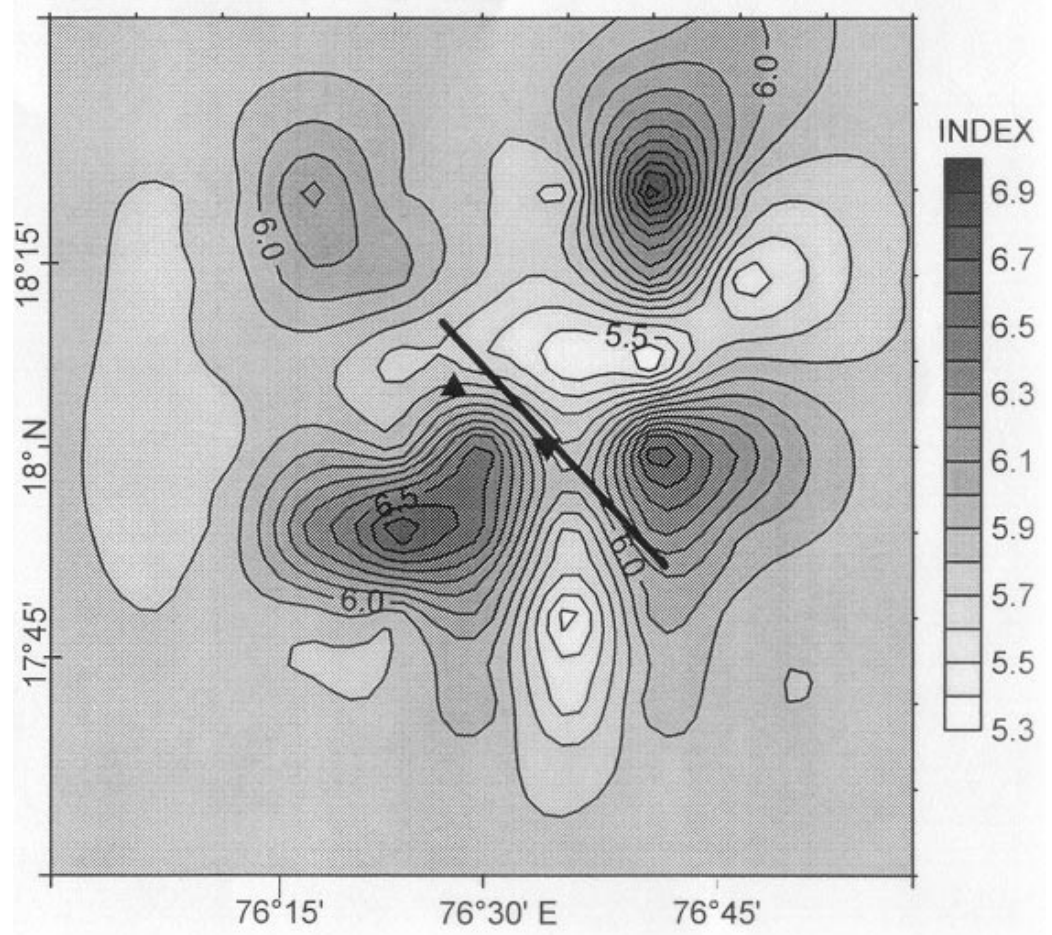

Figure 7. A horizontal slice through the estimated 3D velocity structure of the area at the depth level $6 \mathrm{~km}$. The main shock focus (both the USGS and NGRI estimates) is located at the junction of a high velocity and a low velocity zone. Index shows the velocity values in $\mathrm{km} / \mathrm{s}$. The NGRI and USGS estimates of the main shock are shown by filled inverted and upright triangles, respectively. The fault plane orientation as estimated by HRV (after Baumbach et al 1994) is shown through the NGRI estimate of main shock.

implies that an existing fault zone with lateral heterogeneity in velocity has been the area for stress accumulation.

It may be noted that most of the events have shifted upwards as compared to their initial locations made by 1-D model using HYPO71 computer program. None of them are fixed depth solutions as was the case in the 1D model (figures $4 \mathrm{a}$ and $\mathrm{b}$ ). The RMS residual errors and the hypocentral location errors reduced significantly by the LET method. For example, the average RMS error reduced from 0.93 second to 0.35 second, and the average epicentral error reduced from $4.97 \mathrm{~km}$ to $3.20 \mathrm{~km}$. Similarly the average error in focal depth reduced from $10.73 \mathrm{~km}$ to $4.15 \mathrm{~km}$.

One hundred and eighty eight earthquakes were finally located. Out of these, 29.2, 53.2, and $17.6 \%$ had RMS error less than $0.25 \mathrm{~s}$, between 0.25 and $0.5 \mathrm{~s}$, and between 0.5 and $1.0 \mathrm{~s}$, respectively. $29.5,33,26.9$ and $10.6 \%$ earthquakes were located with error in epicentral location of less than $2 \mathrm{~km}$, between 2 and $5 \mathrm{~km}$, between 5 and $10 \mathrm{~km}$ and greater than $10 \mathrm{~km}$, respectively. Similarly, 30.3, $32.4,32.4$ and $4.9 \%$ earthquakes show error in focal depth of less than $2 \mathrm{~km}$, between 2 and $5 \mathrm{~km}$, between 5 and $10 \mathrm{~km}$ and greater than $10 \mathrm{~km}$ respectively.

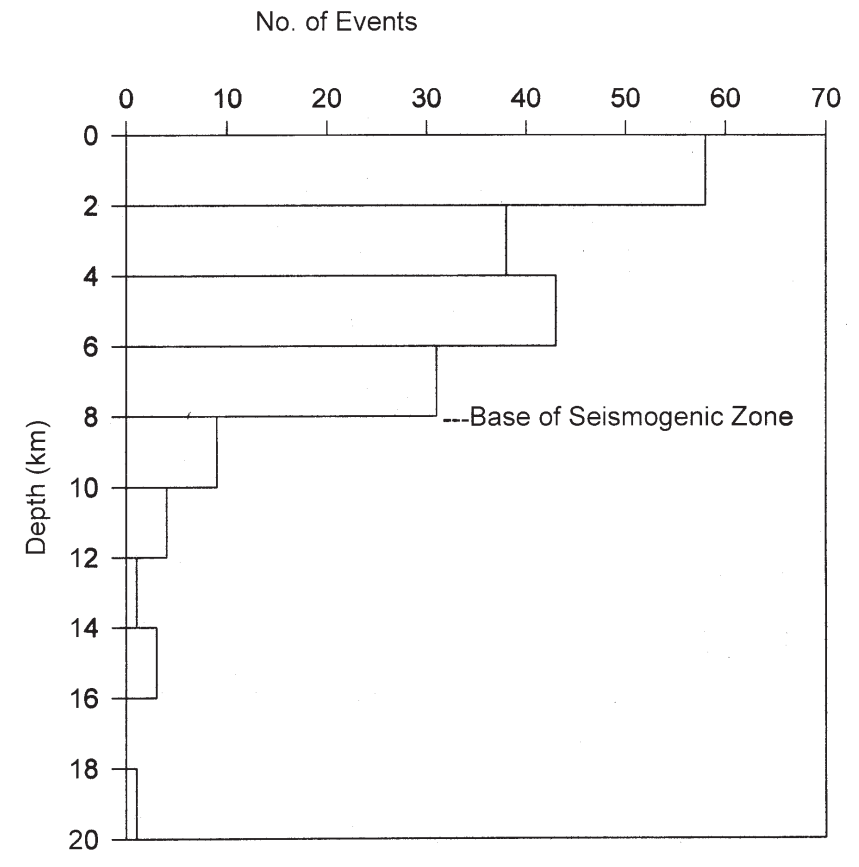

Figure 8. Plot showing the number of events versus depth. The base of the seismogenic zone is at $8 \mathrm{~km}$ (see text).

The number of events versus depth is plotted in figure 8 , which shows that the maximum number of events occurred above the depth of $8 \mathrm{~km}$. It has been suggested by many authors that the depth 


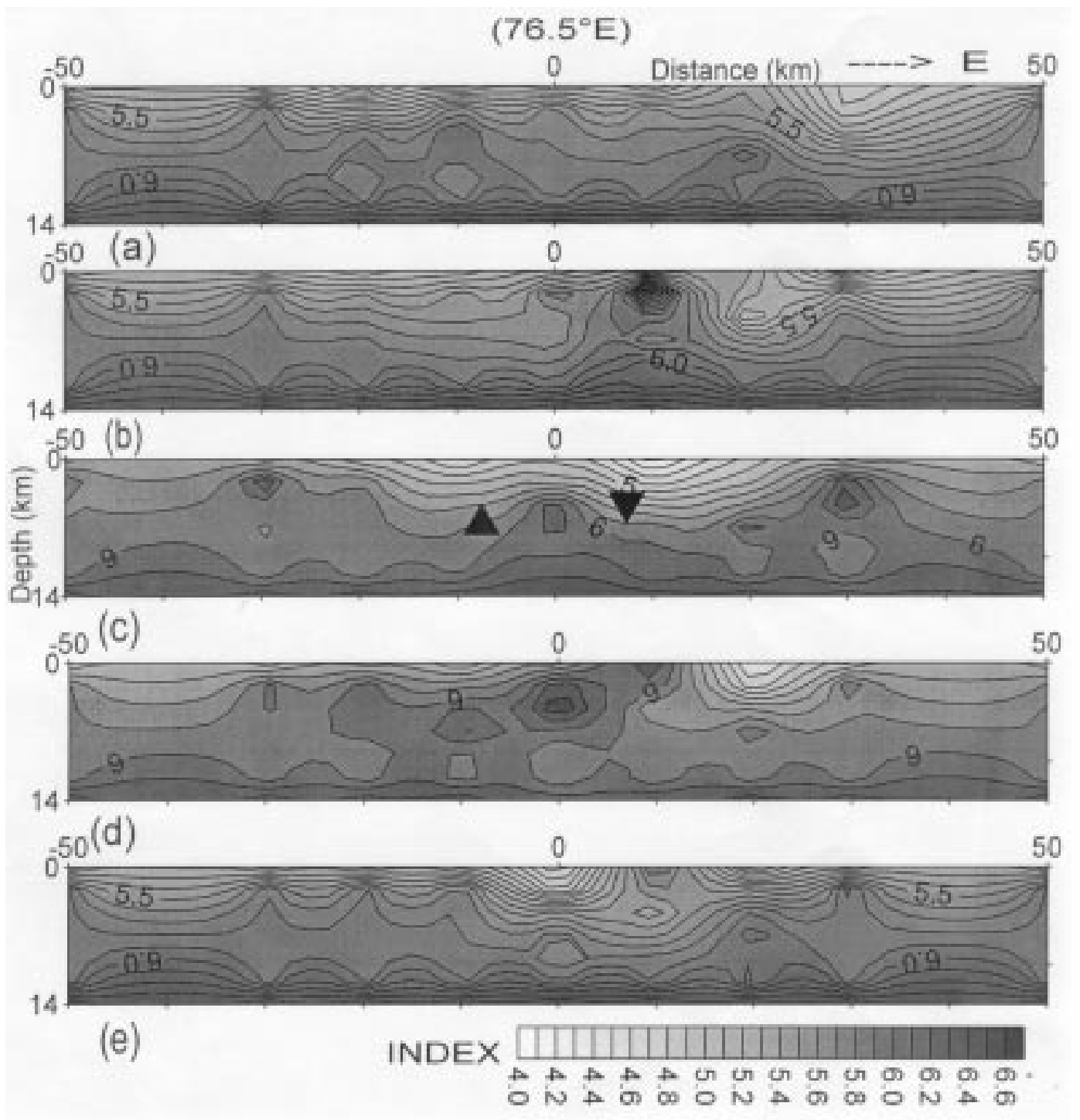

Figure 9. E-W oriented vertical slices through the estimated 3-D velocity structure of the study area. Contoured values of velocities are in $\mathrm{km} / \mathrm{s}$. The slices are $10 \mathrm{~km}$ apart; figure 9 (a) is the northernmost and figure 9 (e) is the southernmost slice, respectively. The central slice (figure 9c) is along latitude $18^{\circ} \mathrm{N}$. The centre of the section shown by 0 is at $76.5^{\circ} \mathrm{E}$. Index shows velocity values in $\mathrm{km} / \mathrm{s}$. The NGRI and USGS estimates of the main shock are shown by filled inverted and upright triangles respectively.

up to which $90 \%$ of the earthquakes occur is the base of the seismogenic zone (e.g. Sibson 1986; Lay and Wallace 1995). They have also suggested that larger magnitude earthquakes tend to nucleate at the base of the seismogenic zone, at the 'fault end'. Different depth values were reported for the main shock (table 1). On the basis of our analysis (e.g. figure 8), we believe that the main shock occurred at a depth range $6-8 \mathrm{~km}$, at the base of the seismogenic zone, and $90 \%$ aftershocks occurred above this zone.

The 3D velocity model estimated in the study area by the LET method is shown in figures 9 and 10 . The velocity values along with their error estimates and spatial resolutions were obtained for the specified grid nodes. The average error in the estimated $P$ wave velocity values at the grid nodes is $\pm 0.07 \mathrm{~km} / \mathrm{s}$ and that in the estimated $V_{P} / V_{S}$ values are \pm 0.016 respectively. The velocity variation along vertical slices in E-W and N-S directions through the center of the grid as well as through two profiles $10 \mathrm{~km}$ and $20 \mathrm{~km}$ on either side are shown in figures 9 and 10 respectively. The aftershocks as well as the main shock locations are superimposed on the central vertical slices (figures $6 \mathrm{a}$ and $\mathrm{b}$ ). It is observed from these slices that most of the earthquakes occur in a region where velocity variation is most rapid both in vertical and lateral directions.

Figure 11( $\mathrm{a}$ and $\mathrm{b}$ ) show the variation of resolution for $P$ wave data in the central $\mathrm{E}-\mathrm{W}$ and $\mathrm{N}$ $\mathrm{S}$ sections respectively. From this figure it is clear that velocity inversion is the best in the central $(40 \mathrm{~km} \times 40 \mathrm{~km}$ areal extent) area, and it becomes 


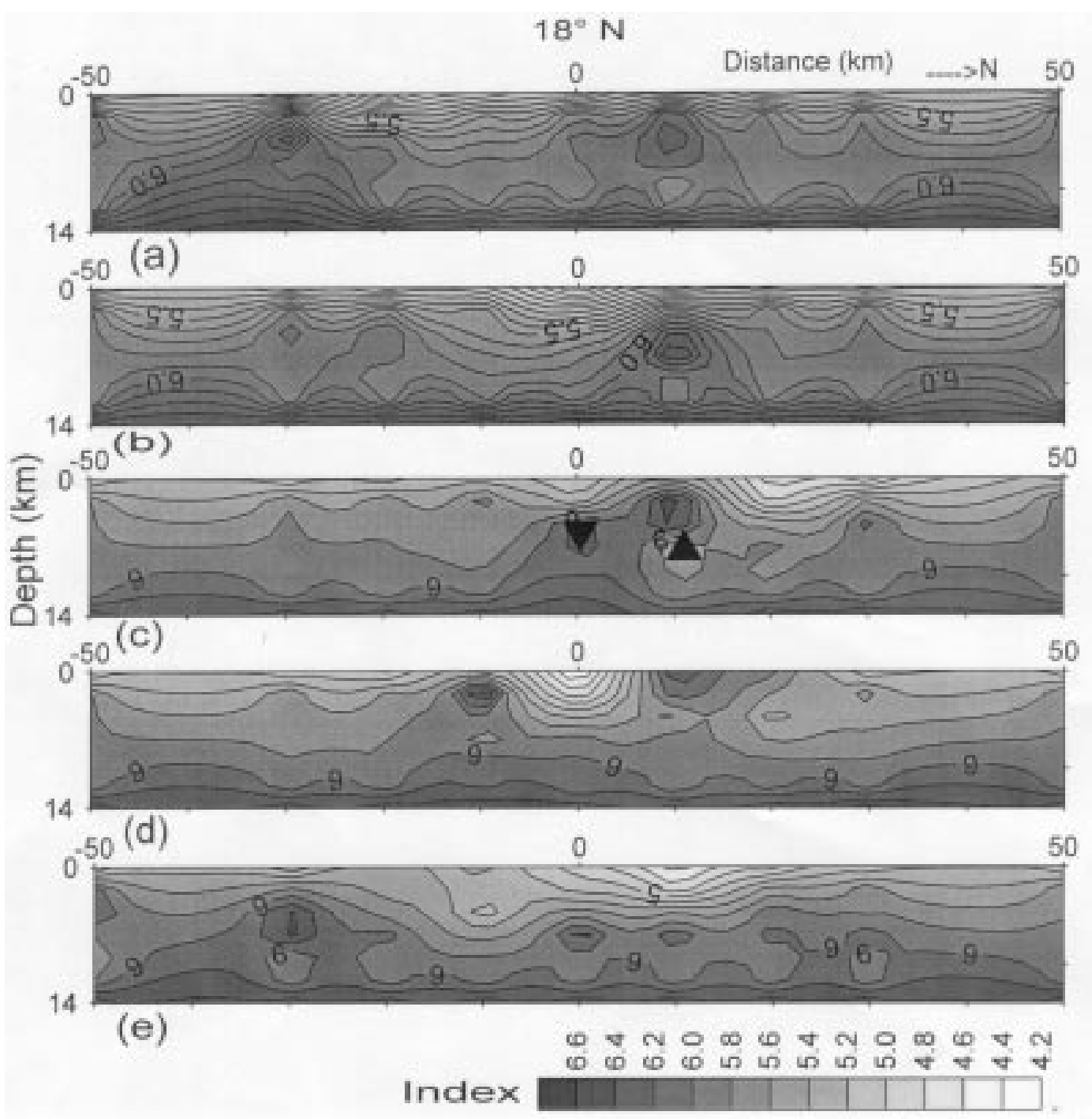

Figure 10. N-S oriented vertical slices through the estimated 3-D velocity structure of the study area. Contoured values of velocities are in $\mathrm{km} / \mathrm{s}$. The slices are $10 \mathrm{~km}$ apart; figure 10(a) is the easternmost and figure 10 (e) is the westernmost slice respectively. The central slice (figure 10c) is along longitude $76.5^{\circ} \mathrm{E}$. The centre of the section shown by 0 is at $18^{\circ} \mathrm{N}$. Index shows velocity values in $\mathrm{km} / \mathrm{s}$. The NGRI and USGS estimates of the main shock are shown by filled inverted and upright triangles respectively.

poorer as we go further away from the centre in the lateral direction. This is attributed to the poor ray coverage laterally as most of the events are concentrated about the center of the study region. Below $8 \mathrm{~km}$ depth the resolution is again poor because the number of earthquakes below this depth is less thereby giving poor ray coverage.

Figure $12(\mathrm{a}$ and $\mathrm{b})$ show the variation of $S$ wave velocity along E-W and N-S sections through the centre of the grid. It shows a pattern broadly similar to respective sections for $P$ wave velocity (figures $9 \mathrm{c}$ and 10c). Figure 13( $\mathrm{a}$ and $\mathrm{b}$ ) show the variation of $V_{P} / V_{S}$ along $\mathrm{E}-\mathrm{W}$ and $\mathrm{N}-\mathrm{S}$ sections through the center of the grid. The hypocentre of the main shock is located in a zone characterized by low value of $V_{P} / V_{S}(\sim 1.64)$. Comparing this figure with figure 6 (a) and (b) we find that the aftershocks too occur within this low $V_{P} / V_{S}$ zone.

\section{Discussion}

The primary benefits of the LET method are the joint evaluation of the three dimensional velocity structure and the earthquake hypocenters, and an understanding of the seismogenic fault(s) from the seismic tomography structure.

The E-W and N-S depth sections of the $P$ wave velocity tomography (figures 9 and 10) show an abrupt change in the velocity structure at the center of the study area $\left(18^{\circ} \mathrm{N}, 76.5^{\circ} \mathrm{E}\right)$. The N-S depth section reveals the presence of a south dipping fault at about five kilometers north of the centre (figure 10); the high velocity zones are found to be displaced vertically by about two kilometers. The hypocentre section in the N-S direction also shows that most of the aftershocks occur along a south dipping plane which meets the surface rup- 


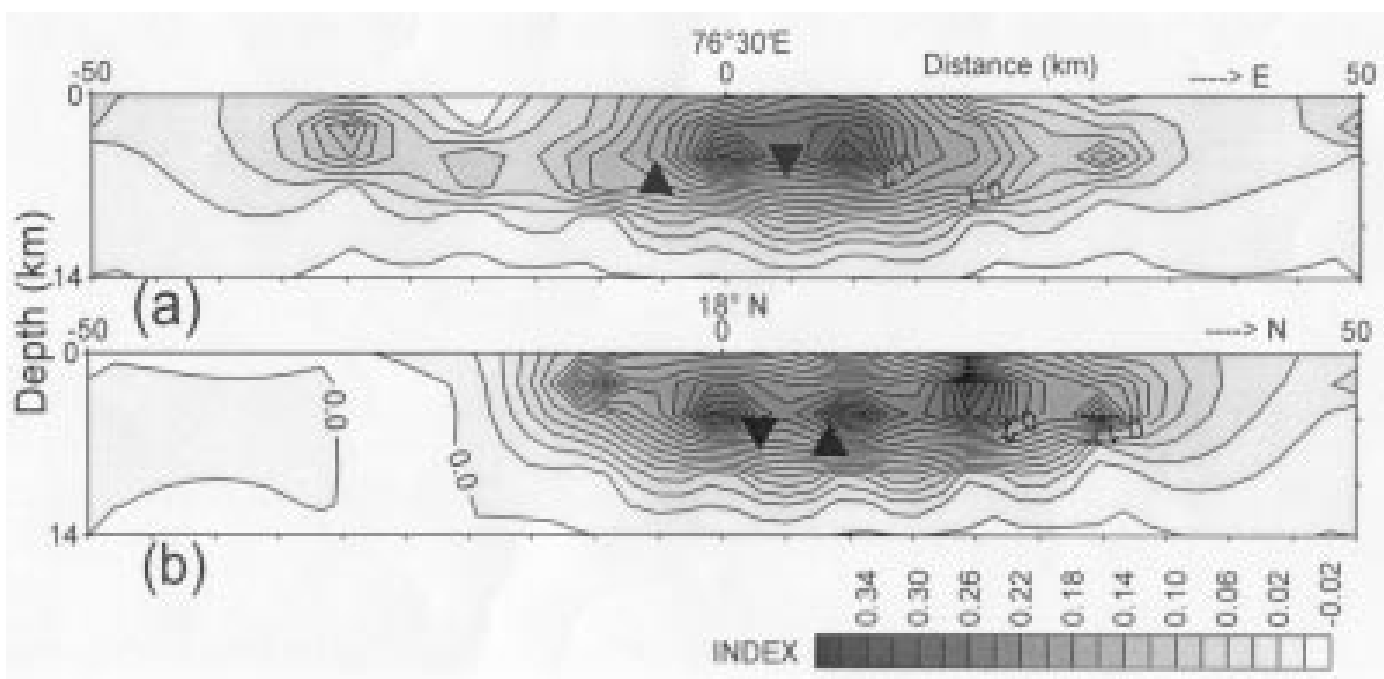

Figure 11. E-W (a) and N-S (b) sections through the center $\left(18^{\circ} \mathrm{N}, 76.5^{\circ} \mathrm{E}\right.$, shown as 0$)$ of the study area showing variations of resolution for $P$ wave velocity. The resolution values are shown along the contours and also in the index. The NGRI and USGS estimates of the main shock are shown by filled inverted and upright triangles respectively.

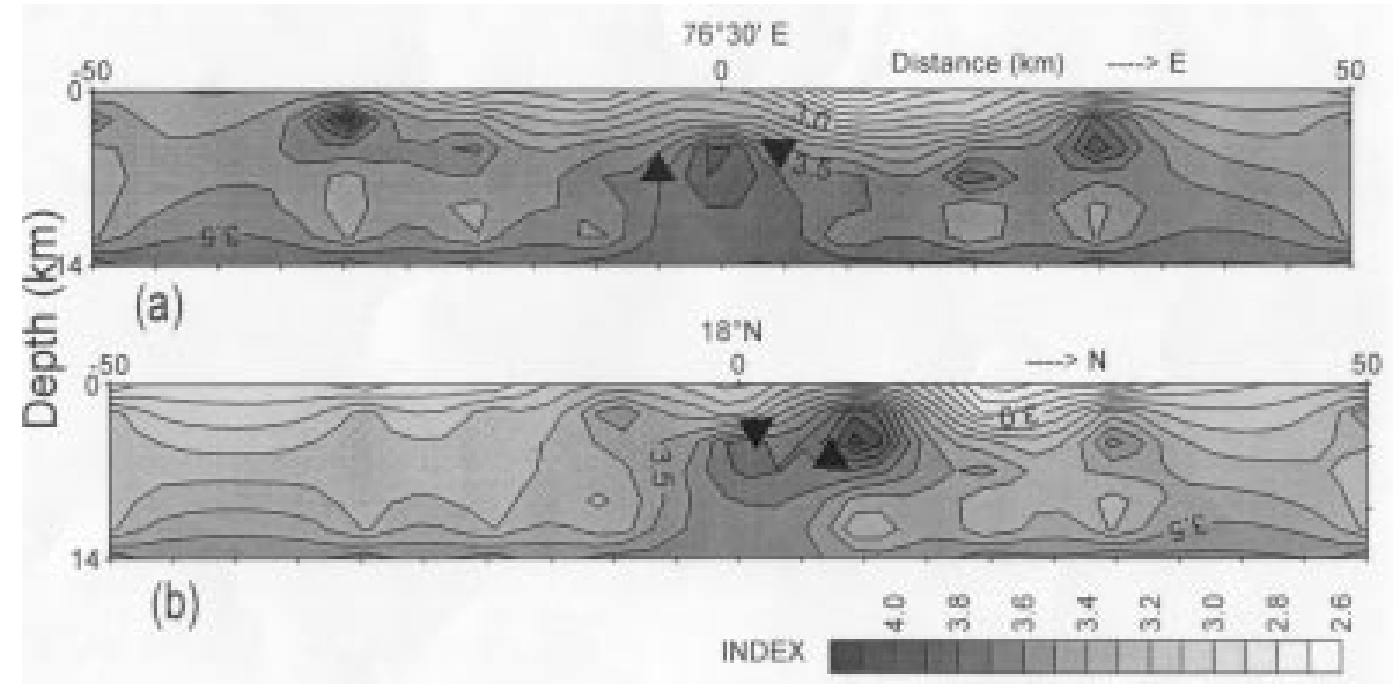

Figure 12. E-W (a) and N-S (b) sections through the center $\left(18^{\circ} \mathrm{N}, 76.5^{\circ} \mathrm{E}\right.$, shown as 0$)$ of the study area showing variations of $S$-wave velocity. The velocity values are shown along the contours in $\mathrm{km} / \mathrm{s}$ and also in the index. The NGRI and USGS estimates of the main shock are shown by filled inverted and upright triangles respectively.

ture (figure 6b). This dipping plane is inferred as the fault plane. Its dip and orientation matches with that of the fault plane inferred from the CMT solution by HRV (figure 1). The E-W depth sections for the velocity structure also show an abrupt lateral change in velocity near the fault zone (figure 9c). Three faults, two in nearly E-W direction and the other in NW-SE direction, were inferred in the epicentral area from the gravity survey (Mishra et al 1994). These fault zones are reflected in the velocity structure. Kayal (2000) interpreted that the main shock as well as the deeper aftershocks (depth $\geq 6 \mathrm{~km}$ ) were generated by reverse faulting along an E-W fault, and the shallower after- shocks (depth $<6 \mathrm{~km}$ ) were generated by strikeslip mechanism along the NW-SE fault. He suggested a fault interaction model with a 'stationary concept' rather than a non-stationary concept of Seeber et al (1996). Rajendran et al (1996) also proposed a 'stationary concept', i.e., existing faults were activated to generate the main shock and the aftershocks.

The post earthquake MT investigation has brought out the existence of a well defined upper crustal conductor in the main shock hypocentre region at an estimated depth of 6-10 km (Sarma et al 1994). The conductor is interpreted to be a fluid enriched rock matrix. They suggested that 


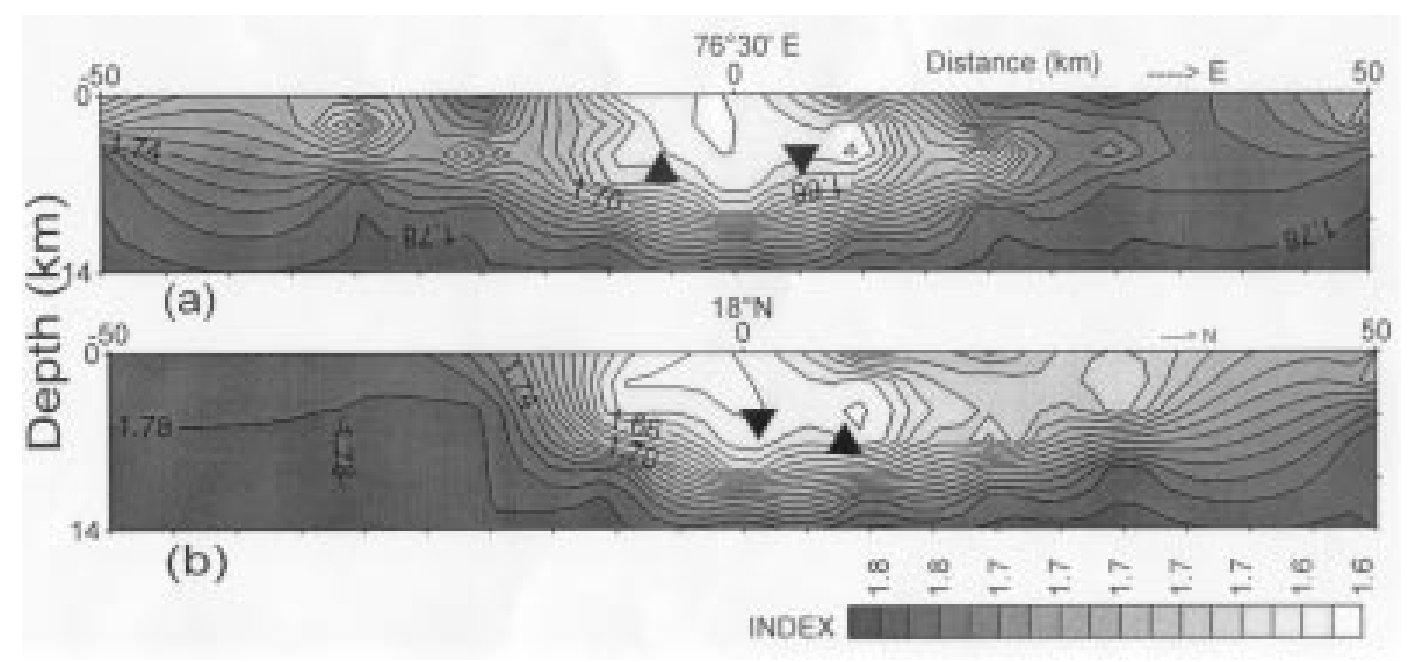

Figure 13. E-W (a) and N-S (b) sections through the center $\left(18^{\circ} \mathrm{N}, 76.5^{\circ} \mathrm{E}\right.$, shown as 0$)$ of the study area showing variation of $V_{P} / V_{S}$. The $V_{P} / V_{S}$ values are shown along the contours and also in the index. The NGRI and USGS estimates of the main shock are shown by filled inverted and upright triangles respectively.

the fluid filled rock matrix might be visualized as a 'weak intrusive' into a hard granitic rock medium. These evidences support a substantial decrease in seismic wave velocity in the hypocentral area. In the seismic tomography, the horizontal slice at a depth of $6 \mathrm{~km}$ reveals these low velocity zones (figure 7).

The N-S sections, which show the variations of velocity with depth, reveal the presence of a low velocity zone (LVZ) at a shallower depth at the centre (figures 10c, d), which is comparable with the inferred E-W fault/the Tirna river. This zone laterally extends to about $30 \mathrm{~km}$ in the east-west direction. At a depth of about $6 \mathrm{~km}$ a high velocity zone (HVZ) is observed $10 \mathrm{~km}$ north of the $18^{\circ} \mathrm{N}$ latitude in the three N-S sections (figures 10a, b and c). This HVZ becomes smaller and it shifts towards a shallower depth (figure 10d). A HVZ is observed at about $8 \mathrm{~km}$ depth at $18^{\circ} \mathrm{N}$ in the central section (figure 10c). This HVZ seems to extend SW at a shallower depth (figure 10b). This indicates a lateral shift of the HVZ due to faulting. Maximum lateral heterogeneities are observed in the main shock hypocentre region along the N-S sections, where both vertical and lateral variations are evident.

The E-W depth sections show progressive shifting of the HVZ from east to west (figure 9b to d) as we go from the northern section (figure $9 \mathrm{~b}$ ) to the southern section (figure 9d). The near surface EW low-velocity trend in figure 9(c) may be associated with the roughly EW-trending Tirna river, which is inferred as surface geomorphological evidence of the E-W fault (Kayal 2000).

It is further observed that in all the sections the velocity variation shows almost a layered structure, away from the earthquake source region. The veloc- ity structure, on the other hand, is quite complex in the main shock hypocentre region. At $6 \mathrm{~km}$ depth slice the main shock hypocentre is located at the junction of the LVZ and the HVZ (figures 7 and 10c). It is inferred that the main shock occurred on the fault plane which separates the LVZ and HVZ laterally. Below the depth of $10 \mathrm{~km}$, the spatial distribution of hypocentres is poor, and it does not allow for proper inversion of the velocity values due to poor ray coverage.

Ninety per cent of the earthquakes occurred above $8 \mathrm{~km}$, which may be attributed to the depth of the seismogenic zone, or the 'fault end'. The main shock nucleated at the 'fault end' at $7 \pm$ $1 \mathrm{~km}$ depth (Kayal 2000). The concentration of the aftershocks above $6 \mathrm{~km}$ (figure $6 \mathrm{a}$ and $\mathrm{b}$ ), on the other hand, indicates that the rupture propagated upwards from the focus of the main shock leading to the surface rupture (Kayal 2000). Estimated centroid depth at $2.6 \pm 1.0 \mathrm{~km}$ (Seeber et al 1996) is compatible with this observation, which implies that the maximum moment release occurred at this depth.

\section{Conclusions}

The aftershock data of 1993 Killari earthquake, recorded by 41 temporary seismograph stations, were used to estimate $3-\mathrm{D}$ velocity structure in the source region by the LET method. The accuracy of earthquake location improved considerably. The main shock occurred at the junction of a LVZ and a HVZ. The lateral heterogeneity has been the source area for stress concentration. The HVZ shows a vertical shift of about $2 \mathrm{~km}$ to the south in the N-S depth section, clearly indicating a fault dipping to 
the south. The hypocentre region also shows a low $V_{P} / V_{S}$ value $(\sim 1.64)$. The main shock hypocentre is located near the base of the seismogenic zone, at the 'fault end', at a depth of $6-8 \mathrm{~km}$, which is very much in agreement with the focal depth $7 \pm 1 \mathrm{~km}$ determined by Chen and Kao (1995).

The velocity values show better resolution in the central $40 \mathrm{~km}$ by $40 \mathrm{~km}$ region with maximum amount of ray coverage. Beyond this area, resolution progressively decreases due to poor ray coverage. Further, most of the earthquakes occurred above $8 \mathrm{~km}$, hence resolution is also better above this depth level.

Most of the relocated aftershocks fall along a planar zone dipping towards south at an angle of about $50^{\circ}$. The main shock location estimated by the NGRI falls on this plane. This plane intersects the surface at the location where surface rupture occurred during the main shock. The aftershocks occurred even up to very shallow depths.

This study reveals that the velocity in the source area varies rapidly in vertical as well as in horizontal direction compared to the adjacent areas. It is attributed to the crustal heterogeneities at the junction of the two faults at the source region due to successive episodes of faulting. This investigation supports the stationary concept, i.e., existing faults with crustal velocity heterogeneity have been the source area for accumulating slow tectonic stress due to the NNE movement of the Indian plate, and the Killari earthquake sequence is a typical example of shallow Stable Continental Region (SCR) earthquakes.

\section{Acknowledgements}

The collated data of the Killari earthquake sequence was obtained from the IMD. S Mukhopadhyay and B K Pradhan are thankful to the Head, Department of Earth Sciences, Indian Institute of Technology, Roorkee (India), and J R Kayal is thankful to the Deputy Director General (Geophysics), GSI, for kind support. Constructive reviews by journal referees helped in improving the manuscript.

\section{References}

Acharyya S K, Kayal J R, Roy A and Chaturvedi R K 1998 Jabalpur earthquake of May 22, 1997: constraint from aftershock study; J. Geol. Soc. India 51 295-304

Aki K and Lee W H K 1976 Determination of three dimensional velocity anomalies under a seismic array using first P-arrival times from local earthquakes; J. Geophys. Res. 81 4381-99
Baumbach M, Grosser H, Schmidt H G, Paulat A, Rietbrock A, Ramakrishna Rao C V, Solomon Raju P, Sarkar D and Mohan I 1994 Study of foreshocks and aftershocks of the intraplate Latur earthquake of September 30, 1993, India; In: Latur Earthquake (ed) H K Gupta, Geol. Soc. India Mem. 35 33-63

Chen W P and Kao H 1995 Seismotectonics of Asia: some recent progress; In: The Tectonic Evaluation of Asia (eds) A Yin and M Harrison, (New York: Cambridge Univ. Press), 37-62

Eberhart-Phillips D 1993 Local earthquake tomography: earthquake source regions; In: Seismic Tomography: Theory and Practice (eds) H M Iyer and K Hirahara (London: Chapman and Hall), 613-643

GSI 1996 Killari Earthquake, 30 September 1993; Geol. Surv. India Sp Pub. $\mathbf{3 7}$ 282pp

Gupta H K, Rastogi B K, Mohan I, Rao C V R K, Sarma S V S and Rao R N M 1998 An investigation into Latur earthquake of September 29, 1993 in Southern India; Tectonophysics 287 299-318

Kayal J R 2000 Seismotectonic study of the two recent SCR earthquakes in central India; J. Geol. Soc.India 55 123138

Kayal J R, De R, Das B, and Chowdhury S N 1996 Aftershock monitoring and focal mechanism studies, Killari earthquake, 30 September 1993. In: Geol. Surv. India Sp. Publ. (eds) P L Narula, S K Sharma and B S R Murthy, 37 165-185

Khattri K N 1994 A hypothesis for the origin of Peninsular seismicity; Curr. Sci. 67 590-597

Krishna J 1992 Seismic zoning maps of India; Curr. Sci. 62 $17-23$

Lay T and Wallace T C 1995 Modern Global Seismology; (New York, USA: Academic Press), $521 \mathrm{pp}$

Lee W H K and Lahr J C 1975 HYPO71 (revised): a computer program for determining hypocentre, magnitude and first motion pattern of local earthquakes; U.S. Geol. Surv. open file Rep. 75-311 1-116

Mishra D C, Gupta S B and Rao M B S V 1994 Space and time distribution of gravity field in earthquake affected areas of Maharashtra, India; In: Latur Earthquake (ed) H K Gupta; Geol. Soc. India Mem. 35 119-126

Mohan I and Rao M N 1994 A field study of Latur (India) earthquake of 30th September 1993; In: Latur Earthquake (ed) H K Gupta; Geol. Soc. India Mem. 35 7-32

Pradhan B K 1999 Seismic tomographic image of Latur and its surroundings; unpubl. M.Tech. Dissertation, University of Roorkee. 70p.

Rajendran C P Rajendran K and John B 1996 The 1993 Killari (Latur) - Central India earthquake: An example of fault reactivation in the Precambrian crust; Geology 24 651-654

Rajendran K and Rajendran C P 1998 Characteristics of the 1997 Jabalpur earthquake and their bearing on its mechanism; Curr. Sci. 74 168-174

Ramchandran C and Keshavani M 1997 Fault segmentation and earthquake hazard zones in Deccan Trap Region : gravity evidence; J. Geol. Soc. India 49 23-32

Ramesh D S and Estabrook C H 1998 Rupture histories of two stable continental region earthquakes of India; Proc. Indian Acad. Sci. (Earth Planet. Sci.) 107 1225-233

Sarma S V S, Virupakshi G, Harinarayan T, Murthy D N, Pravakar S, Rao E, Veeraswamy K, Rao M, Sarma M V C and Gupta K R B 1994 A wide band magnetotelluric study of the Latur earthquake region, Maharashtra, India; In: Latur Earthquake (ed) H K Gupta; Geol. Soc. India Mem. 35 101-118

Seeber L, Ekstrom G, Jain S K, Murthy C V R, Chandak N and Armbruster J G 1996 The 1993 Killari earthquake 
in central India: A new fault in Mesozoic basalt flows?; J. Geophys. Res. $1018543-8560$

Sibson R H 1986 Earthquakes and rock deformation in crustal fault zones; Ann. Rev. Earth Planet Sci. 14149 175

Simpson D W and Nicholson C 1985 Changes in $V_{P} / V_{S}$ with depth: Implications for appropriate velocity models, improved earthquake locations, and material properties of upper crust; Bull. Seism. Soc. Am. 75 1105-1123

Thurber C H 1983 Earthquake location and three dimensional crustal structure in the Coyote Lake Area, Central California; J. Geophys. Res. 88 8226-8236

Wadia D N 1998 Geology of India; Tata McGraw-Hill Edition $508 \mathrm{p}$.

MS received 17 January 2001; revised 15 July 2001 